\title{
Update meta-analysis on 1790G/A polymorphism and cancer risk: Evidence from 26 studies
}

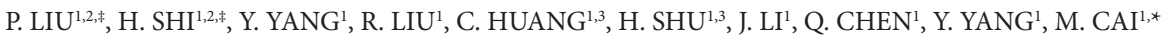 \\ ${ }^{1}$ Department of Orthopaedics, Shanghai Tenth People's Hospital, Tongji University, School of Medicine, Shanghai, China; ${ }^{2}$ Department of \\ First Clinical Medical College, Nanjing Medical University, Nanjing, Jiangsu, China; ${ }^{3}$ The medical department of Soochow University, Suzhou, \\ Jiangsu, China \\ ${ }^{*}$ Correspondence: cmdoctor@163.com \\ ${ }^{*}$ Contributed equally to this work.
}

Received August 29, 2013 / Accepted October 24, 2013

\begin{abstract}
The results from the published studies on the association between hypoxia-inducible factor-1(Hif-1/HIF-1) polymorphisms and cancer risk are conflicting. The common 1790G/A rs11549467) genetic polymorphism has been reported to be functional and may contribute to genetic susceptibility to cancers. However, the association between 1790G/A (rs11549467) and cancer risk remains inconclusive.

To better understand the role of 1790G/A (rs11549467) polymorphism in cancer, we conducted this comprehensive metaanalysis encompassing 6337 cases and 9302 controls.

Overall, the 1790G/A (rs11549467) genetic polymorphism was associated with higher cancer risk. In the stratified analysis, significant associations were found between the Hif-1/HIF-1 1790G/A polymorphism and lung cancer, pancreatic cancer and oral squamous cell carcinoma. We also observed that the AA genotype might modulate lung cancer $(\mathrm{OR}=5.42[2.75-10.70])$, pancreatic cancer $(\mathrm{OR}=9.30[1.12-77.61])$ and oral squamous cell carcinoma $(\mathrm{OSCC})(\mathrm{OR}=13.32[1.57-112.75])$ risk comparing with the GG genotype. Moreover, a significantly increased cancer risk was found in homozygote comparison (AA vs. GG) and recessive genetic model (AA vs. AG/GG) among Caucasian population. When stratified by study design, significantly elevated susceptibility to cancer was found among hospital-based studies.

These findings suggested that the 1790G/A (rs11549467) genetic polymorphism may contribute to the susceptibility of cancers except gynecologic cancer, especially in homozygote comparison and recessive genetic model among Caucasian population, and this SNP was significantly associated with the lung cancer, pancreatic cancer and oral squamous cell carcinoma (OSCC). The phenomenon also indicates that the SNP functions as a recessive mutation needs to be verified or linked with functional studies.
\end{abstract}

Key words: Hif-1/HIF-1, 1790G/A, cancer, genetic polymorphism, meta-analysis

Cancer is one of the leading causes of death in the world. It has become a worldwide public health problem[1]. The exact mechanism of carcinogenesis is not yet fully elucidated[2]. Recently, it has become clear that genetic variation contributes to the development and progression of cancer[2,3]. However, due to various reasons, including considerable heterogeneity of the disease, the identification of susceptibility genes is difficult and most associations have not been replicated.

One of the most important features of tumors is hypoxia. Intratumoral hypoxia occurs when cells are located further from a functional blood vessel than is required for adequate diffusion of oxygen, resulting in rapid tumor cell proliferation and developing abnormal blood vessels[4]. Hypoxia conditions in tumor tissues induce a molecular response, which drives the activation of transcription factors. Among these, hypoxia-inducible factor-1(Hif-1/HIF-1) plays an essential role in adaptive responses to reduced oxygen levels $[5,6]$.

Hif-1/HIF-1 is a dimeric protein complex, consisting of $\alpha$ and $\beta$ subunits. The activity of Hif- $1 /$ HIF- 1 is regulated predominantly through the stability of the subunit [7]. Koshiji et al. demonstrated that Hif-1/HIF-1 (PASD8) inhibits the DNA mismatch repair system (MSH2 and MSH6), which is responsible for genetic instability [8]. Other researchers have also reported that hypoxia down regulates the expression of 
DNA double-stranded break repair genes $[9,10][11,12]$. These data support the concept that defective DNA repair pathways cause genomic instability within the tumor microenvironment. PASD8 (Hif-1/HIF-1) is overexpressed in $>90 \%$ of colon, lung and prostate cancers, whereas no expression was detected in corresponding normal tissues [13], indicating a role of Hif-1/ HIF-1 in cancer. It is over expressed in several human cancers, such as head-neck, colon, breast, stomach, pancreas, prostate, kidney, esophagus, endometrial, and non-small-cell lung cancer [14-19]. The target genes of Hif-1/HIF-1 are particularly relevant to cancer, encoding angiogenic factors, proliferation/ survival factors, glucose transporters and glycolytic enzymes [20]. As such, variability in this protein is likely to influence individual risk to this pathology.

A number of investigators have studied the possible association between the Hif-1/HIF-1 polymorphisms and cancer risk, but the results have been conflicting [21-38]. Thus, the association between the Hif-1/HIF-1 polymorphisms and cancers requires further investigation. In an attempt to clarify this inconsistency, we have combined all the published studies of hospital and population up to August.2013 in a meta-analysis to give a comprehensive picture of the role of Hif-1/HIF-1a gene using multiple research methods and models.

In this study, a comprehensive meta-analysis was performed on previous reports to investigate the association of Hif-1/HIF-1a 1790G/A (rs11549467) polymorphisms with all cancers, different kinds of cancers, and different kinds of populations.

\section{Materials and methods}

Search strategy and data extraction. In this meta-analysis, a comprehensive literature research of the US National Library of Medicine's PubMed database, ISI Web of Knowledge, Medline, Embase and Google Scholar Search (update to August,2013) was conducted using the search terms including "Hif-1/HIF-1a" or "hypoxia-inducible factor-1" or "1790G/A" or "rs11549467" or "A588T (Ala588Thr, G1790A, rs11549467)" , "polymorphisms" or "variation" or "mutation" or "SNP", "tumour" or "tumor" or "cancer" or "neoplasm" or "phyma" or "oncoma" or "knub" or "carcinoma" or "malignancy", and the combined phrases in order to obtain all genetic studies on the relationship of 1790G/A polymorphism and cancers. We also used a hand search of references of original studies or reviewed articles on this topic to identify additional studies. Eligible studies were selected according to the following explicit inclusion criteria: (1) a case control study on the association between $1790 \mathrm{G} / \mathrm{A}$ polymorphism and cancer risk, (2)detailed number of different genotypes for estimating an odds ratio (OR) with 95\% confidence interval (CI), (3) when several publications reported on the same population data, the largest or most complete study was chosen, (4) cases with carcinomas were diagnosed by histopathology, (5) animal studies, case reports, review articles, abstracts, editorials, reports with incomplete data, and studies based on pedigree data were excluded(Fig. 1). For each eligible study, the following information was recorded: the first author's name, the year of

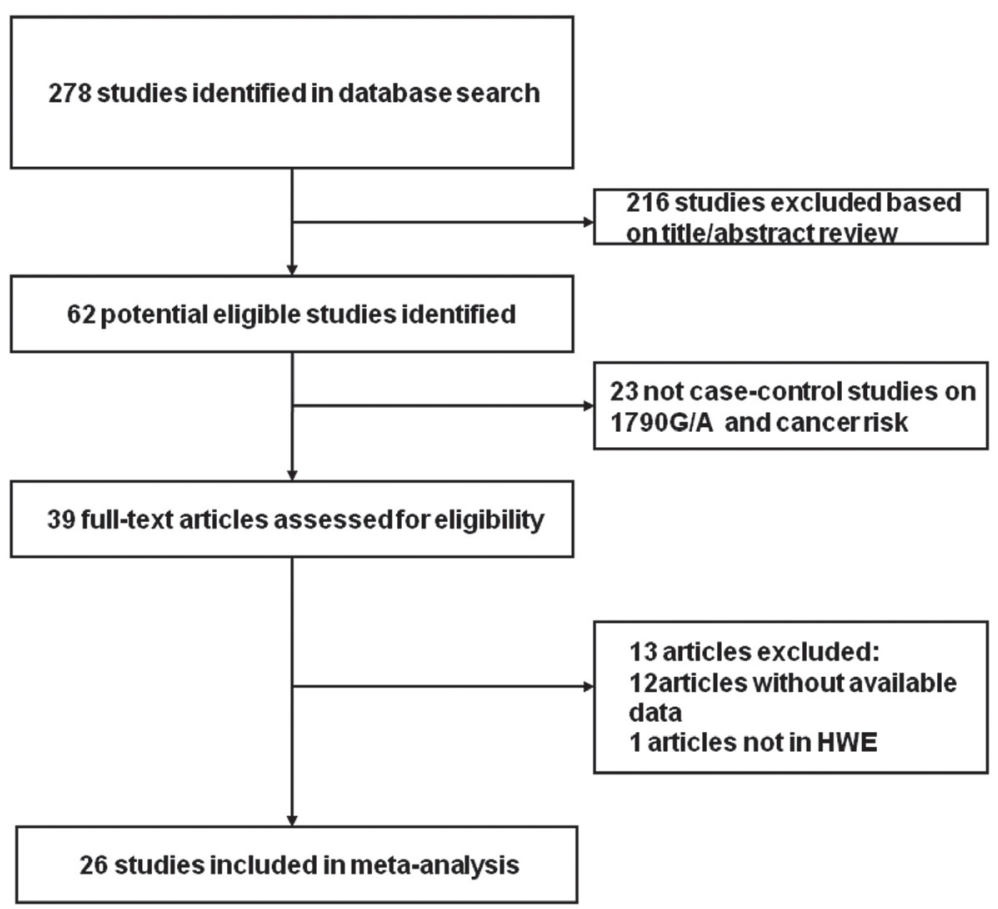

Figure 1. Flow diagram of study identification. 
publication, patients, ethnicity, genotyping methods, sources of control, racial descent of the study population, genotype and allele distributions and main results of each study.

Statistical analysis. The strength of relationship between $1790 \mathrm{G} / \mathrm{A}$ polymorphism and cancer was assessed by using crude OR with $95 \%$ CI. We examined the association between the $1790 \mathrm{G} / \mathrm{A}$ polymorphism and cancer risk using the following genetic models: homozygote comparison (AA vs. GG), heterozygote comparison (AG vs. GG), dominant genetic model (AA/AG vs. GG), recessive genetic model (AA vs. AG/GG) and additive model (A vs. G). Firstly, we checked the Hardy-Weinberg equilibrium (HWE) in controls for each study. Then we performed Q-test for evaluating the heterogeneity [39]. Fixed effects model was used to pool the data when the P-value of Q-test $\geq 0.05$; otherwise, random effects model was selected [40]. $\mathrm{I}^{2}$ was also used to assess the heterogeneity in this meta-analysis. If $\mathrm{I}^{2}>50 \%$,the heterogeneity exists[41]. We also performed sensitivity analysis and subgroup analysis to explore the reason of heterogeneity. Both funnel plot and Egger's test were used to assess the publication bias $(\mathrm{P}<0.05$ was representative of statistical significance) [42]. All statistical analysis were performed using STATA 12.0 software and Review Manager 5.2.

\section{Results}

Eligible studies. Overall,26 relevant studies involving 6337 cases and 9302 controls were selected in this metaanalysis[21,26,27,29,30,32,43-62]. The main characteristics of these studies were shown in Table 1. Genotype and allele distributions of $1790 \mathrm{G} / \mathrm{A}$ polymorphism among cancer cases and controls and $P$ value of HWE in controls were shown in Table 1 and 2. All studies were case-control studies, including three oral squamous cell carcinoma (OSCC) studies [46,51,59], three prostate cancer studies[29,44,60], three renal cell carcinoma studies[21,49,57], three breast cancer studies $[30,32,50]$, two gynecologic carcinoma studies[27,53], two colorectal studies[26,62], two pancreatic cancer studies[55,58], three lung cancer studies[47,54,56] and the others(including head and neck squamous cell carcinoma(HNSCC)[43], transitional cell carcinoma of the bladder[45], hepatocellular carcinoma[52], gastric cancer[52], glottic cancer[61]). Cancers were histological or pathological in most studies. There were fourteen studi es[32,43,45,46,48,50,52-57,60,61] of Asian descent, twelve studies[21,26,27,29,30,44,47,49,51,58,61,62] of Caucasian descent. Population-based controls were carried out in 9

Table1. Main characteristics of included studies in the meta-analysis.

\begin{tabular}{|c|c|c|c|c|c|c|}
\hline Studies(cancer type) & Country & Ethnicity & Genotype assay & Source of control & Case/control & $p$ \\
\hline Tanimoto 2003 HNSCC & Japan & Asian & PCR-Sequencing & Population & $55 / 110$ & 0.655 \\
\hline Munoz-Guerra 2009 OSCC & Spain & Caucasian & PCR-RFLP & Hospital & $64 / 139$ & 0.693 \\
\hline Li 2007 prostate cancer & USA & Caucasian & PCR-RFLP & Population & $1066 / 1264$ & 0.810 \\
\hline Orr-Urtreger 2007 prostate cancer & Israel & Caucasian & PCR-RFLP & Population & $200 / 300$ & 0.954 \\
\hline Clifford 2001 renal cell carcinoma & UK & Caucasian & PCR-Sequencing & Hospital & $48 / 144$ & 0.866 \\
\hline Apaydin 2008 breast cancer & Turkey & Caucasian & PCR-RFLP & Population & $102 / 102$ & 0.840 \\
\hline Kim 2008 breast cancer & Korea & Asian & PCR-Sequencing & Hospital & $90 / 102$ & 0.060 \\
\hline Konac 2007 gynecologic cancer & Turkey & Caucasian & PCR-RFLP & Hospital & $102 / 107$ & - \\
\hline Fransen 2006 colorectal cancer & Sweden & Caucasian & PCR-RFLP & Hospital & $198 / 256$ & 0.775 \\
\hline Naidu 2009 breast cancer & Malaysia & Asian & PCR-RFLP & Hospital & $410 / 275$ & 0.180 \\
\hline Ruiz-Tovar 2012 pancreatic cancer & Spain & Caucasian & PCR-RFLP & Hospital & $59 / 152$ & 0.675 \\
\hline Kuo 2012 non-small-cell lung cancer & China & Asian & PCR-RFLP & Hospital & $285 / 300$ & 0.154 \\
\hline Wang 2011 pancreatic cancer & China & Asian & PCR-Sequencing & Hospital & $263 / 271$ & 0.486 \\
\hline Hsiao 2010 hepatocellular carcinoma & China & Asian & PCR-RFLP & Hospital & $102 / 347$ & 0.701 \\
\hline Chen 2009 OSCC & China & Asian & PCR-RFLP & Population & $174 / 347$ & 0.701 \\
\hline Konac 2009 lung cancer & Turkey & Caucasian & PCR-RFLP & Hospital & $141 / 156$ & 0.936 \\
\hline Li 2009 gastric cancer & China & Asian & PCR-LDR & Hospital & $87 / 106$ & 0.764 \\
\hline Nadaoka 2008 bladder cnacer & Japan & Asian & PCR-RFLP & Hospital & $219 / 461$ & 0.330 \\
\hline Kim 2011 cervical cancer & Korea & Asian & SNaPShot & Hospital & $199 / 214$ & 0.136 \\
\hline Qin 2012 renal cell carcinoma & China & Asian & Taqman & Hospital & $620 / 623$ & 0.420 \\
\hline Morris 2009 renal cell carcinoma & Poland & Caucasian & Taqman & Population & $325 / 309$ & 0.662 \\
\hline Putra 2011 lung cancer & Japan & Asian & PCR-Sequencing & Hospital & $83 / 110$ & 0.655 \\
\hline Knechtel 2010 colorectal cancer & Austria & Caucasian & Taqman & Population & $367 / 2156$ & 0.405 \\
\hline Li 2012 prostate cancer & China & Asian & Taqman & Population & $662 / 716$ & 0.554 \\
\hline Mera-Menendez 2013 glottic cancer & Spain & Caucasian & PCR-RFLP & Population & $111 / 139$ & 0.693 \\
\hline Shieh 2010 OSCC & China & Asian & PCR-Sequencing & Hospital & $305 / 96$ & 0.711 \\
\hline
\end{tabular}

$p$ Value of Hardy-Weinberg equilibrium in controls. 
Table 2. Distribution of 1790G/A(rs11549467) polymorphism and the main results of eligible studies.

\begin{tabular}{|c|c|c|c|c|c|c|c|}
\hline \multirow[t]{2}{*}{ Stuies(cancer type) } & \multirow{2}{*}{$\begin{array}{c}\text { Case } \\
\text { (AA/AG/GG) }\end{array}$} & \multirow{2}{*}{$\begin{array}{c}\text { Control } \\
\text { (AA/AG/GG) }\end{array}$} & \multicolumn{5}{|c|}{$\mathrm{OR}(95 \% \mathrm{CI})$} \\
\hline & & & AA vs.GG & AG vs.GG & AA/AG vs.GG & AA vs.AG/GG & A vs.G \\
\hline Tanimoto 2003 HNSCC & $\begin{array}{c}55 \\
(0 / 4 / 51)\end{array}$ & $\begin{array}{c}110 \\
(0 / 9 / 101)\end{array}$ & - & $\begin{array}{c}0.88 \\
(0.26-3.00)\end{array}$ & $\begin{array}{c}0.88 \\
(0.26-3.00)\end{array}$ & - & $\begin{array}{c}0.88 \\
(0.27-2.94)\end{array}$ \\
\hline Munoz-Guerra 2009 OSCC & $\begin{array}{c}64 \\
(3 / 21 / 40)\end{array}$ & $\begin{array}{c}139 \\
(0 / 9 / 130)\end{array}$ & $\begin{array}{c}22.56 \\
(1.14-445.89)\end{array}$ & $\begin{array}{c}7.58 \\
(3.22-17.88)\end{array}$ & $\begin{array}{c}8.67 \\
(3.73-20.16)\end{array}$ & $\begin{array}{c}15.88 \\
(0.81-312.08)\end{array}$ & $\begin{array}{c}7.99 \\
(3.63-17.58)\end{array}$ \\
\hline Li 2007 prostate cancer & $\begin{array}{c}1066 \\
(0 / 13 / 1053)\end{array}$ & $\begin{array}{c}1264 \\
(0 / 17 / 1247)\end{array}$ & - & $\begin{array}{c}0.91 \\
(0.44-1.87)\end{array}$ & $\begin{array}{c}0.91 \\
(0.44-1.87)\end{array}$ & - & $\begin{array}{c}0.91 \\
(0.44-1.87)\end{array}$ \\
\hline $\begin{array}{l}\text { Orr-Urtreger } 2007 \text { prostate } \\
\text { cancer }\end{array}$ & $\begin{array}{c}200 \\
(0 / 2 / 198)\end{array}$ & $\begin{array}{c}300 \\
(0 / 2 / 298)\end{array}$ & - & $\begin{array}{c}1.51 \\
(0.21-10.77)\end{array}$ & $\begin{array}{c}1.51 \\
(0.21-10.77)\end{array}$ & - & $\begin{array}{c}1.50 \\
(0.21-10.71)\end{array}$ \\
\hline $\begin{array}{l}\text { Clifford } 2001 \text { renal cell } \\
\text { carcinoma }\end{array}$ & $\begin{array}{c}48 \\
(0 / 1 / 47)\end{array}$ & $\begin{array}{c}144 \\
(0 / 4 / 140)\end{array}$ & - & $\begin{array}{c}0.74 \\
(0.08-6.83)\end{array}$ & $\begin{array}{c}0.74 \\
(0.08-6.83)\end{array}$ & - & $\begin{array}{c}0.75 \\
(0.08-6.77)\end{array}$ \\
\hline Apaydin 2008 breast cancer & $\begin{array}{c}102 \\
(0 / 0 / 102)\end{array}$ & $\begin{array}{c}102 \\
(0 / 4 / 98)\end{array}$ & - & $\begin{array}{c}0.11 \\
(0.01-2.01)\end{array}$ & $\begin{array}{c}0.11 \\
(0.01-2.01)\end{array}$ & - & $\begin{array}{c}0.11 \\
(0.01-2.04)\end{array}$ \\
\hline Kim 2008 breast cancer & $\begin{array}{c}90 \\
(0 / 3 / 87)\end{array}$ & $\begin{array}{c}102 \\
(1 / 7 / 94)\end{array}$ & $\begin{array}{c}0.36 \\
(0.01-8.95)\end{array}$ & $\begin{array}{c}0.46 \\
(0.11-1.85)\end{array}$ & $\begin{array}{c}0.41 \\
(0.10-1.58)\end{array}$ & $\begin{array}{c}0.37 \\
(0.02-9.29)\end{array}$ & $\begin{array}{c}0.37 \\
(0.10-1.38)\end{array}$ \\
\hline $\begin{array}{l}\text { Konac } 2007 \text { gynecologic } \\
\text { cancer }\end{array}$ & $\begin{array}{c}102 \\
(0 / 2 / 47)\end{array}$ & $\begin{array}{c}107 \\
(0 / 0 / 107)\end{array}$ & - & $\begin{array}{c}5.35 \\
(0.25-112.76)\end{array}$ & $\begin{array}{c}5.35 \\
(0.25-112.76)\end{array}$ & - & $\begin{array}{c}5.30 \\
(0.25-110.99)\end{array}$ \\
\hline $\begin{array}{l}\text { Fransen } 2006 \text { colorectal } \\
\text { cancer }\end{array}$ & $\begin{array}{c}198 \\
(0 / 9 / 189)\end{array}$ & $\begin{array}{c}256 \\
(0 / 9 / 247)\end{array}$ & - & $\begin{array}{c}1.31 \\
(0.51-3.36)\end{array}$ & $\begin{array}{c}1.31 \\
(0.51-3.36)\end{array}$ & - & $\begin{array}{c}1.30 \\
(0.51-3.31)\end{array}$ \\
\hline Naidu 2009 breast cancer & $\begin{array}{c}410 \\
(6 / 72 / 332)\end{array}$ & $\begin{array}{c}275 \\
(2 / 41 / 232)\end{array}$ & $\begin{array}{c}2.10 \\
(0.42-10.48)\end{array}$ & $\begin{array}{c}1.23 \\
(0.81-1.86)\end{array}$ & $\begin{array}{c}1.27 \\
(0.84-1.91)\end{array}$ & $\begin{array}{c}2.03 \\
(0.41-10.12)\end{array}$ & $\begin{array}{c}1.28 \\
(0.88-1.87)\end{array}$ \\
\hline $\begin{array}{l}\text { Ruiz-Tovar } 2012 \text { pancreatic } \\
\text { cancer }\end{array}$ & $\begin{array}{c}59 \\
(3 / 2 / 54)\end{array}$ & $\begin{array}{c}152 \\
(0 / 10 / 142)\end{array}$ & $\begin{array}{c}18.30 \\
(0.93-360.19)\end{array}$ & $\begin{array}{c}0.53 \\
(0.11-2.48)\end{array}$ & $\begin{array}{c}1.31 \\
(0.43-4.02)\end{array}$ & $\begin{array}{c}18.89 \\
(0.96-371.56)\end{array}$ & $\begin{array}{c}2.14 \\
(0.82-5.56)\end{array}$ \\
\hline $\begin{array}{l}\text { Kuo } 2012 \text { non-small-cell } \\
\text { lung cancer }\end{array}$ & $\begin{array}{c}285 \\
(41 / 94 / 150)\end{array}$ & $\begin{array}{c}300 \\
(11 / 74 / 215)\end{array}$ & $\begin{array}{c}5.34 \\
(2.66-10.73)\end{array}$ & $\begin{array}{c}1.82 \\
(1.26-2.63)\end{array}$ & $\begin{array}{c}2.28 \\
(1.62-3.21)\end{array}$ & $\begin{array}{c}4.41 \\
(2.22-8.78)\end{array}$ & $\begin{array}{c}2.35 \\
(1.77-3.11)\end{array}$ \\
\hline $\begin{array}{l}\text { Wang } 2011 \text { pancreatic } \\
\text { cancer }\end{array}$ & $\begin{array}{c}263 \\
(1 / 64 / 198)\end{array}$ & $\begin{array}{c}271 \\
(0 / 22 / 249)\end{array}$ & $\begin{array}{c}3.77 \\
(0.15-93.07)\end{array}$ & $\begin{array}{c}3.66 \\
(2.18-6.15)\end{array}$ & $\begin{array}{c}3.72 \\
(2.21-6.24)\end{array}$ & $\begin{array}{c}3.10 \\
(0.13-76.51)\end{array}$ & $\begin{array}{c}3.39 \\
(2.06-5.58)\end{array}$ \\
\hline $\begin{array}{l}\text { Hsiao } 2010 \text { hepatocellular } \\
\text { carcinoma }\end{array}$ & $\begin{array}{c}102 \\
(0 / 15 / 87)\end{array}$ & $\begin{array}{c}347 \\
(0 / 14 / 333)\end{array}$ & - & $\begin{array}{c}4.10 \\
(1.91-8.82)\end{array}$ & $\begin{array}{c}4.10 \\
(1.91-8.82)\end{array}$ & - & $\begin{array}{c}3.85 \\
(1.83-8.13)\end{array}$ \\
\hline Chen 2009 OSCC & $\begin{array}{c}174 \\
(1 / 20 / 153)\end{array}$ & $\begin{array}{c}347 \\
(0 / 14 / 333)\end{array}$ & $\begin{array}{c}6.52 \\
(0.26-160.91)\end{array}$ & $\begin{array}{c}3.11 \\
(1.53-6.32)\end{array}$ & $\begin{array}{c}3.26 \\
(1.62-6.59)\end{array}$ & $\begin{array}{c}6.01 \\
(0.24-148.26)\end{array}$ & $\begin{array}{c}3.28 \\
(1.83-8.13)\end{array}$ \\
\hline Konac 2009 lung cancer & $\begin{array}{c}141 \\
(0 / 1 / 140)\end{array}$ & $\begin{array}{c}156 \\
(0 / 2 / 154)\end{array}$ & - & $\begin{array}{c}0.55 \\
(0.05-6.13)\end{array}$ & $\begin{array}{c}0.55 \\
(0.05-6.13)\end{array}$ & - & $\begin{array}{c}0.55 \\
(0.05-6.12)\end{array}$ \\
\hline Li 2009 gastric cancer & $\begin{array}{c}87 \\
(0 / 13 / 74)\end{array}$ & $\begin{array}{c}106 \\
(0 / 6 / 100)\end{array}$ & - & $\begin{array}{c}2.93 \\
(1.06-8.06)\end{array}$ & $\begin{array}{c}2.93 \\
(1.06-8.06)\end{array}$ & - & $\begin{array}{c}2.77 \\
(1.03-7.45)\end{array}$ \\
\hline $\begin{array}{l}\text { Nadaoka } 2008 \text { bladder } \\
\text { cancer }\end{array}$ & $\begin{array}{c}219 \\
(0 / 15 / 204)\end{array}$ & $\begin{array}{c}461 \\
(0 / 40 / 421)\end{array}$ & - & $\begin{array}{c}0.77 \\
(0.42-1.43)\end{array}$ & $\begin{array}{c}0.77 \\
(0.42-1.43)\end{array}$ & - & $\begin{array}{c}0.78 \\
(0.43-1.43)\end{array}$ \\
\hline Kim 2011 cervical cancer & $\begin{array}{c}199 \\
(0 / 12 / 187)\end{array}$ & $\begin{array}{c}214 \\
(1 / 13 / 200)\end{array}$ & $\begin{array}{c}0.36 \\
(0.01-8.80)\end{array}$ & $\begin{array}{c}0.99 \\
(0.44-2.22)\end{array}$ & $\begin{array}{c}0.92 \\
(0.41-2.03)\end{array}$ & $\begin{array}{c}0.36 \\
(0.01-8.81)\end{array}$ & $\begin{array}{c}0.86 \\
(0.40-1.85)\end{array}$ \\
\hline $\begin{array}{l}\text { Qin } 2012 \text { renal cell } \\
\text { carcinoma }\end{array}$ & $620(0 / 45 / 575)$ & $\begin{array}{c}623 \\
(0 / 39 / 584)\end{array}$ & - & $\begin{array}{c}1.17 \\
(0.75-1.83)\end{array}$ & $\begin{array}{c}1.17 \\
(0.75-1.83)\end{array}$ & - & $\begin{array}{c}1.17 \\
(0.75-1.80)\end{array}$ \\
\hline $\begin{array}{l}\text { Morris } 2009 \text { renal cell } \\
\text { carcinoma }\end{array}$ & $\begin{array}{c}325 \\
(2 / 10 / 313)\end{array}$ & $\begin{array}{c}309 \\
(0 / 15 / 294)\end{array}$ & $\begin{array}{c}4.70 \\
(0.22-98.24)\end{array}$ & $\begin{array}{c}0.63 \\
(0.28-1.42)\end{array}$ & $\begin{array}{c}0.75 \\
(0.35-1.63)\end{array}$ & $\begin{array}{c}4.78 \\
(0.23-100.04)\end{array}$ & $\begin{array}{c}0.88 \\
(0.42-1.85)\end{array}$ \\
\hline Putra 2011 lung cancer & $\begin{array}{c}83 \\
(2 / 9 / 72)\end{array}$ & $\begin{array}{c}110 \\
(0 / 9 / 101)\end{array}$ & $\begin{array}{c}7.00 \\
(0.33-148.00)\end{array}$ & $\begin{array}{c}1.40 \\
(0.53-3.71)\end{array}$ & $\begin{array}{c}1.71 \\
(0.68-4.35)\end{array}$ & $\begin{array}{c}6.78 \\
(0.32-143.12)\end{array}$ & $\begin{array}{c}1.99 \\
(0.83-4.78)\end{array}$ \\
\hline $\begin{array}{l}\text { Knechtel } 2010 \text { colorectal } \\
\text { cancer }\end{array}$ & $\begin{array}{c}367 \\
(0 / 11 / 356)\end{array}$ & $\begin{array}{c}2156 \\
(0 / 76 / 2080)\end{array}$ & - & $\begin{array}{c}0.85 \\
(0.44-1.61)\end{array}$ & $\begin{array}{c}0.85 \\
(0.44-1.61)\end{array}$ & - & $\begin{array}{c}0.85 \\
(0.45-1.60)\end{array}$ \\
\hline Li 2012 prostate cancer & $\begin{array}{c}662 \\
(1 / 47 / 614)\end{array}$ & $\begin{array}{c}716 \\
(0 / 31 / 685)\end{array}$ & $\begin{array}{c}3.35 \\
(0.14-82.30)\end{array}$ & $\begin{array}{c}1.69 \\
(1.06-2.70)\end{array}$ & $\begin{array}{c}1.73 \\
(1.09-2.75)\end{array}$ & $\begin{array}{c}3.25 \\
(0.13-79.90)\end{array}$ & $\begin{array}{c}1.74 \\
(1.10-2.74)\end{array}$ \\
\hline $\begin{array}{l}\text { Mera-Menendez } 2013 \\
\text { glottic cancer }\end{array}$ & $\begin{array}{c}111 \\
(0 / 4 / 107)\end{array}$ & $\begin{array}{c}139 \\
(0 / 9 / 130)\end{array}$ & - & $\begin{array}{c}0.54 \\
(1.16-1.80)\end{array}$ & $\begin{array}{c}0.54 \\
(0.16-1.80)\end{array}$ & - & $\begin{array}{c}0.55 \\
(0.17-1.80)\end{array}$ \\
\hline Shieh 2010 OSCC & $\begin{array}{c}305 \\
(0 / 24 / 281)\end{array}$ & $\begin{array}{c}96 \\
(0 / 7 / 89)\end{array}$ & - & $\begin{array}{c}1.09 \\
(0.45-2.61)\end{array}$ & $\begin{array}{c}1.09 \\
(0.45-2.61)\end{array}$ & - & $\begin{array}{c}1.08 \\
(0.46-2.55)\end{array}$ \\
\hline
\end{tabular}


studies, while hospital-based controls were carried out in 17 studies. All studies were reported in English. The genotyping methods contained the classic polymerase chain reactionrestriction fragment length polymorphism ( PCR-RFLP) assay, PCR-sequencing, PCR-LDR, SnaPShot and Taqman. The genotype distributions of controls were all in agreement with HWE except for one studie not estimable [27].

Meta-analysis. Overall, as shown in Table 3, we observed that the $1790 \mathrm{G} / \mathrm{A}$ (rs11549467) polymorphism increased the cancer risk in the homozygote (AA vs. GG, OR=4.37[2.61-7.33]) (Fig.2), heterozygote model (AG vs. GG, OR=1.39[1.06-1.82]) (Fig.3), dominant genetic model $(\mathrm{OR}=1.46[1.11-1.92])$ (Fig.4), recessive model $(\mathrm{OR}=3.87[2.32-6.46])$ (Fig.5) and additive model (A vs. G, $\mathrm{OR}=1.49$ [1.15-1.95]) (Fig.6) when all the eligible studies were pooled into the meta-analysis. In the heterozygote comparison, dominant genetic and additive models, all the $P$ values of Q-test were lower than 0.05 and $\mathrm{I}^{2}$ values were higher than $50 \%$. So we performed the sensitivity analysis by deleting one single study from overall pooled analysis each time to check the influence of the removed data. However, the results revealed that no extreme sensitive study changed the between-study heterogeneities.

We then evaluated the effects of the 1790G/A(rs11549467) polymorphism according to specific cancer types, different ethnicities, different detection method and different sources of control. As shown in Table 3, we found that
1790G/A(rs11549467) polymorphism elevated oral squamous cell carcinoma (OSCC) risk and lung cancer risk in all the five models (AA vs. GG, AG vs. GG, AA/AG vs. GG, AA vs. AG/GG, A vs. G). For oral squamous cell carcinoma (OSCC), the ORs[95\%CI] were 13.32[1.57-112.75], 2.96[1.05-8.31], 3.15 [1.05-9.47], 10.70[1.25-91.51] and 3.09[1.07-8.93] respectively; for lung cancer, the ORs[95\%CI] were 5.42[2.75-10.70], $1.72[1.22-2.42], 2.14[1.56-2.94], 4.52[2.31-8.83]$ and 2.26[1.742.95] respectively. For pancreatic cancer, significant association was found in the following models: AA vs. GG: $\mathrm{OR}=9.30[1.12$ 77.61]; $A G$ vs. $G G$ : $O R=2.90[1.82-4.62]$; $A A$ vs. AG/GG: $\mathrm{OR}=8.65[1.04-71.65]$; $\mathrm{A}$ vs. $\mathrm{G}: \mathrm{OR}=3.12$ [2.01-4.84]. We also found significant association between 1790G/A (rs11549467) polymorphism and hepatocellular and gastric cancer in heterozygote, recessive and additive model. In the stratified analysis by ethnicity, significantly increased risks were found in Asian in all genetic models tested (Table 3). For Caucasian, significant associations were observed in homozygote comparison (AA vs. $\mathrm{GG}, \mathrm{OR}=12.40[2.19-70.22]$ ) and recessive model (AA vs. $\mathrm{AG} / \mathrm{GG}, \mathrm{OR}=11.37[2.02-63.93])$. According to the source of controls, signification effects in all genetic models were observed in hospital-based studies; while in population-based studies, significant association was not observed in any genetic model. According to the detection method, signification effects in most genetic models were observed in PCR-RFLP subgroup; while in other subgroup, significant association was not observed in any genetic model.

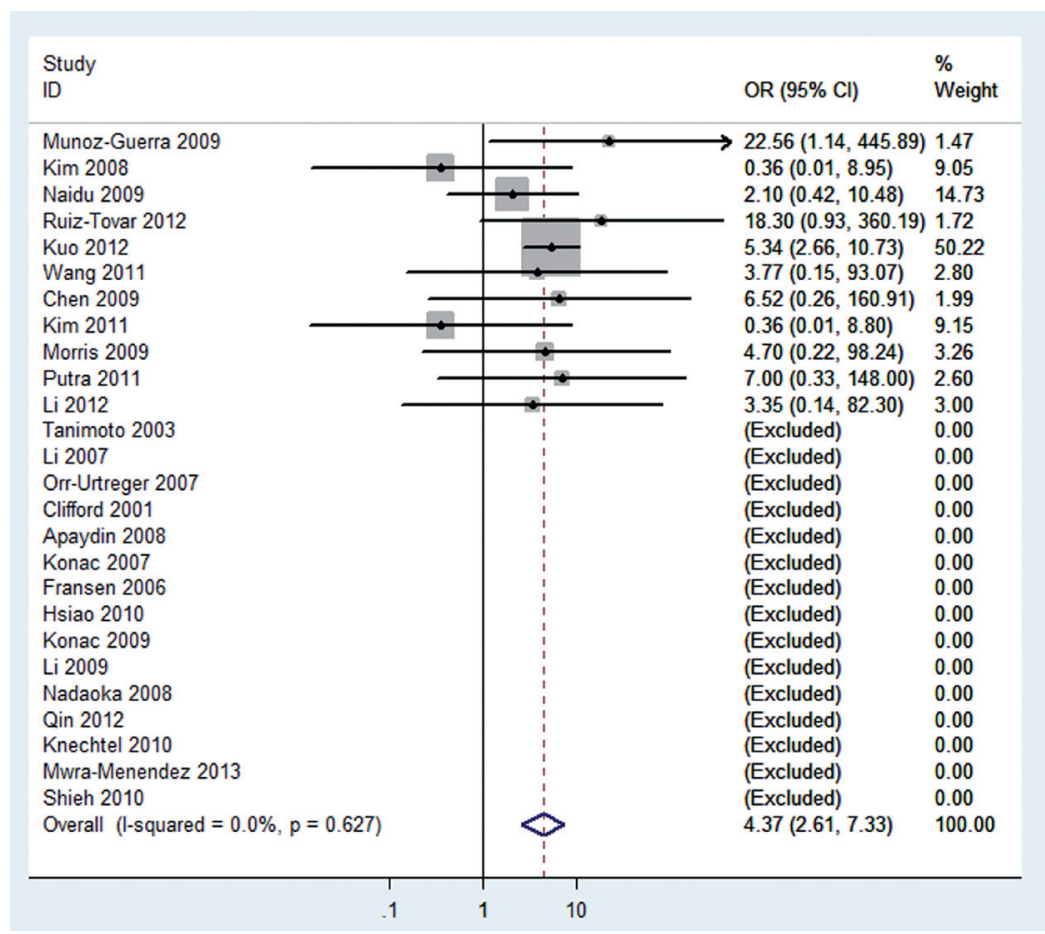

Figure 2. The forest plot of AA vs. GG of 1790G/A polymorphism and overall cancer risk(fixed model). The overall OR is shown. The OR of each study is marked with a grey square. The \%weight of OR is indicated by a shadow. The overall OR is indicated by blue diamond. 


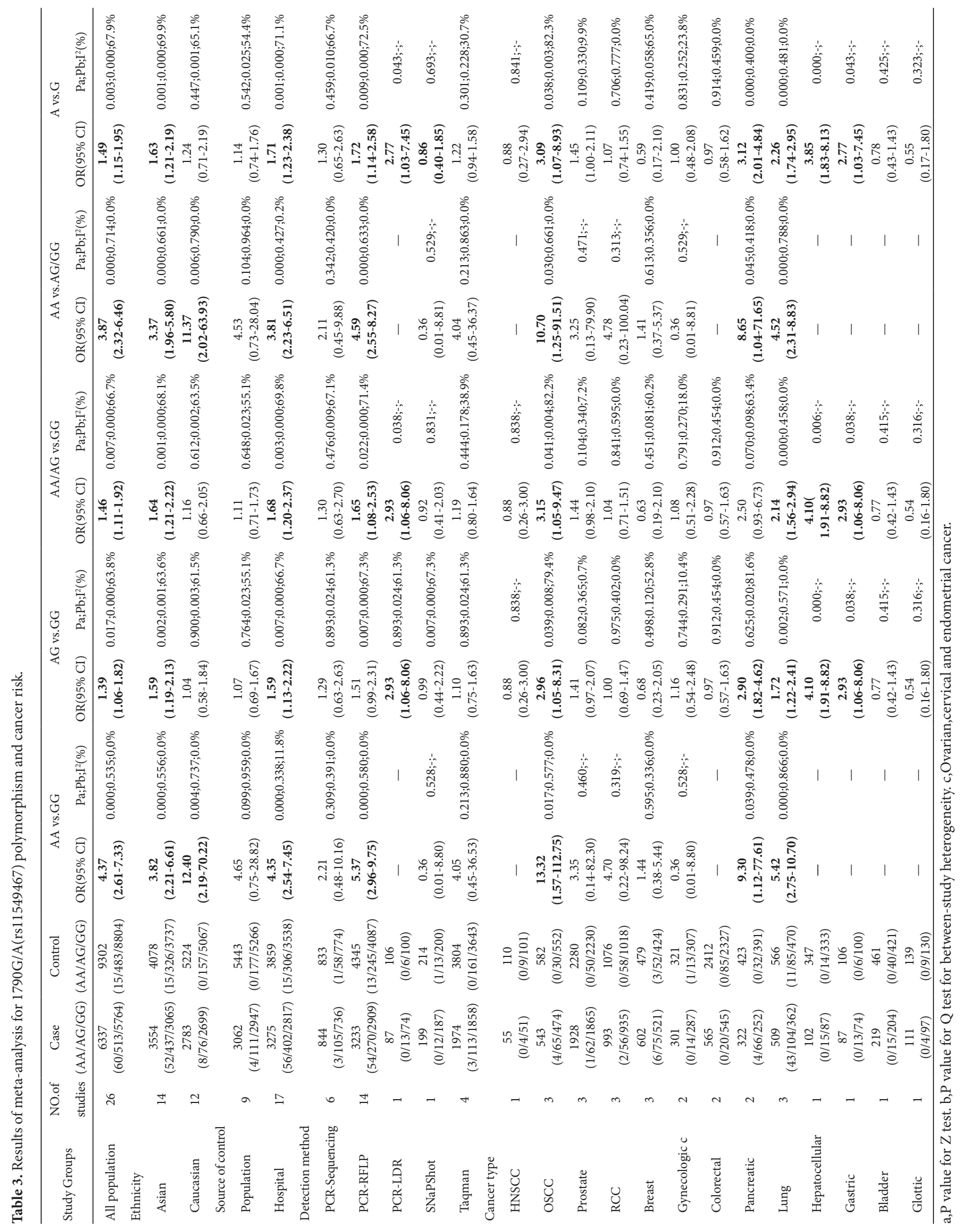




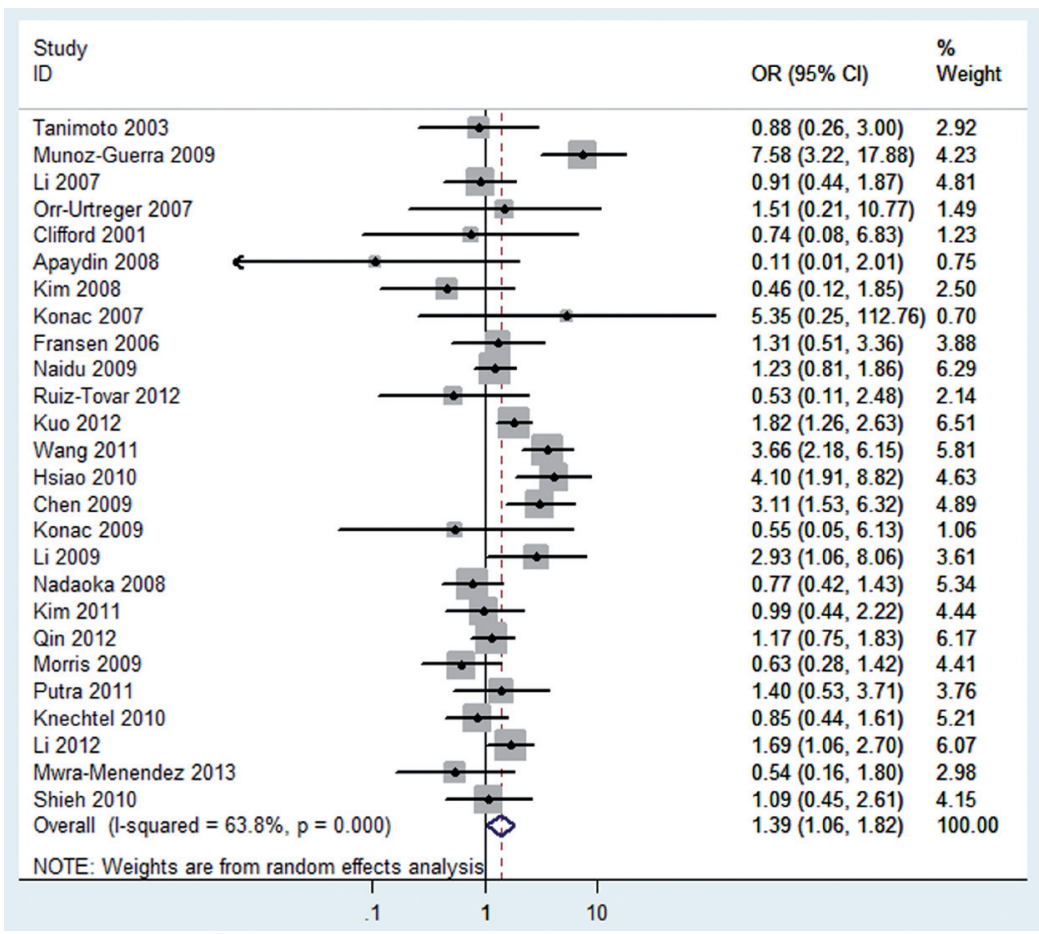

Figure 3. The forest plot of AG vs. GG of $1790 \mathrm{G} / \mathrm{A}$ polymorphism and overall cancer risk(random model).

The overall OR is shown. The OR of each study is marked with a grey square. The \%weight of OR is indicated by a shadow. The overall OR is indicated by blue diamond.

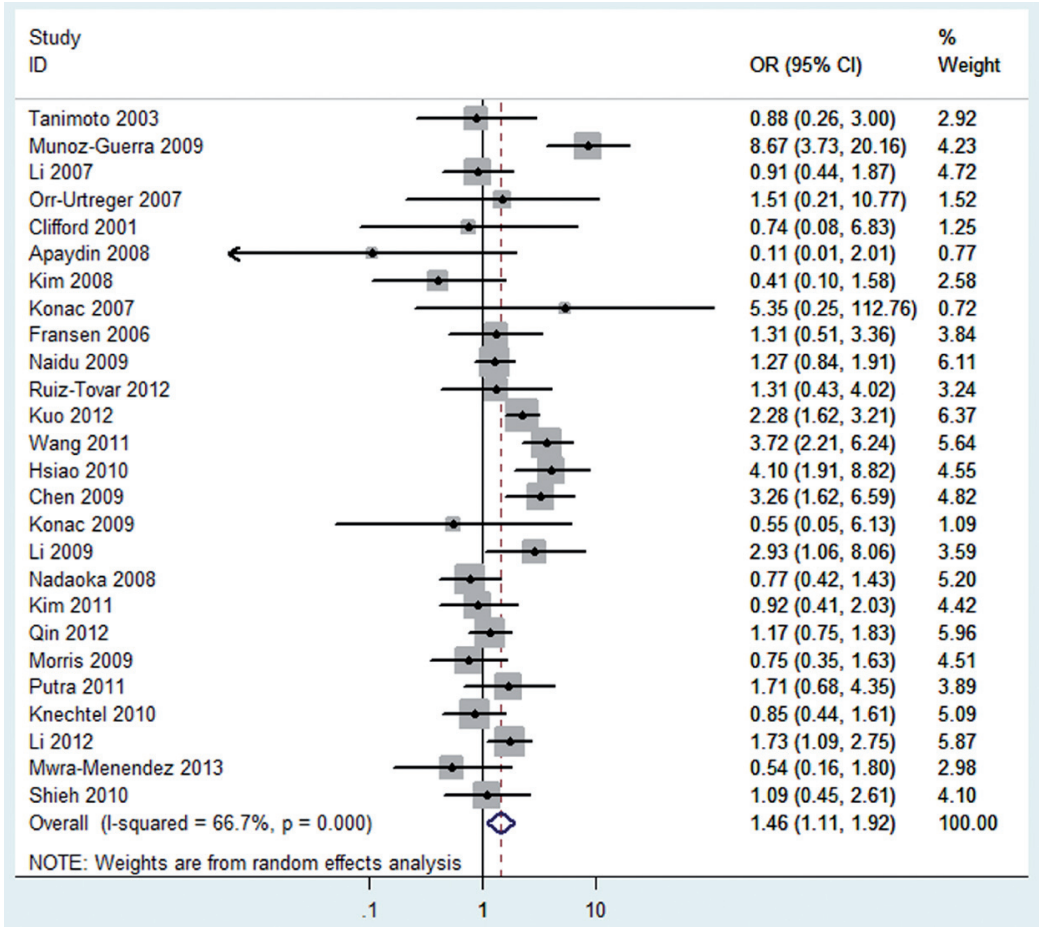

Figure 4. The forest plot of AA/AG vs. GG of $1790 \mathrm{G} / \mathrm{A}$ polymorphism and overall cancer risk(random model).

The overall OR is shown. The OR of each study is marked with a grey square. The \%weight of OR is indicated by a shadow. The overall OR is indicated by blue diamond. 


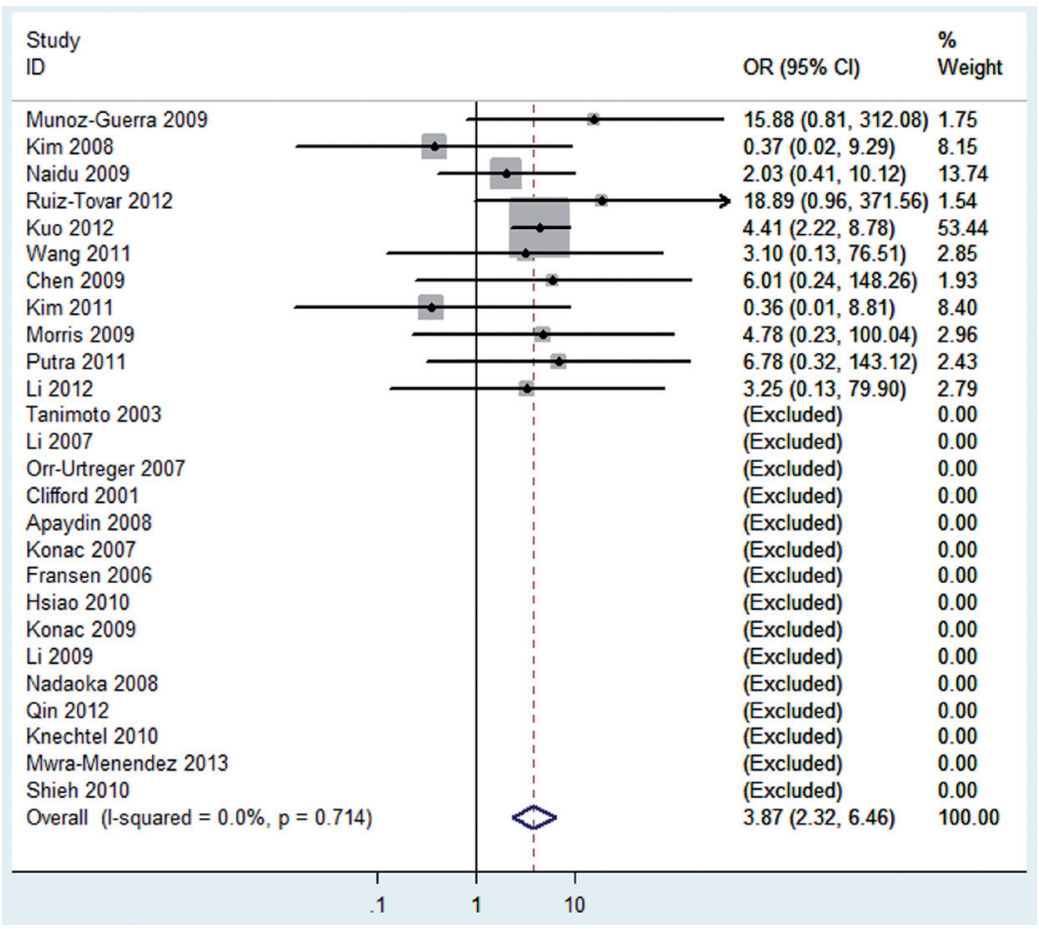

Figure 5. The forest plot of AA vs. AG/GG of 1790G/A polymorphism and overall cancer risk(fixed model).

The overall OR is shown. The OR of each study is marked with a grey square. The \%weight of OR is indicated by a shadow. The overall OR is indicated by blue diamond.

Publication bias. Both Begg's funnel plot and Egger's test were performed to assess the publication bias. The shape of the funnel plots did not reveal any evidence of obvious asymmetry in the overall meta-analysis. Then, Egger's test was used to provide statistical evidence of funnel plot symmetry. The results still did not present any obvious evidence of publication bias (AA vs.GG. $P=0.533$; AG vs. GG. $P=0.271$; AA/AG vs.GG, $P=0.243$; AA vs. AG/GG, $P=0.658$; A vs. G. $P=0.183$ ).

\section{Discussion}

This meta-analysis of 26 studies involving 6337 cases and 9302 controls was conducted in order to yield a valid conclusion concerning the potential association between 1790G/A (rs11549467) polymorphism and cancer risk. HIF-1 plays a major role in cancer progression and metastasis through activation of various genes that are linked to regulation of angiogenesis, cell survival, and energy metabolism $[63,64]$. The Hif-1/HIF-1 was previously found to be implicated in the development and progression of cancer $[63,64]$. In 2009, Zhao $\mathrm{T}$ et al. [65] have done a meta-analysis on the relationship between Hif-1/HIF-1 and cancers, but their study only referred to the case-control studies before 2009 . The polymorphisms analyzed in the present study consist of $\mathrm{G}$ to A nucleotide substitutions at positions 1790 of the exon 12 of the Hif-1/HIF-1. Because a study by Tanimoto [64] showed both of the substitutions displayed an increased transactivation capacity of Hif-1/HIF-1 $\alpha$ in vitro, the presence of the variant alleles might be associated with increased cancer susceptibility. However, studies focusing on the association of the Hif-1/HIF-1 polymorphism with cancer susceptibility had controversial conclusions[21,26,27,29,30,32,43-59]. The lack of concordance across many of these studies reflects limitation in the studies, such as small sample sizes, ethnic difference and research methodology and so on. Meta-analysis is a powerful tool for summarizing the results from different studies by producing a single estimate of the major effect with enhanced precision.

In our analysis, there was significant association between this polymorphism and oral squamous cell carcinoma (OSCC) risk under the homozygote model. Patients carrying the A allele at position 1790 of the exon 12 of the Hif-1/HIF-1 had more cancer risk than did patients homozygous for the $\mathrm{G}$ allele. Besides, for oral squamous cell carcinoma (OSCC), pancreatic cancer and lung cancer, the associations were more significant in the recessive model than in the dominant model. These results suggested that homozygous AA had stronger effects on an individual's phenotype than heterozygous AG. So individuals with AA genotype could have higher risk of the three cancer type than that with AG genotype. The pooled effects for homozygote comparison and dominant model comparison suggested a significant association between the 1790G/A 


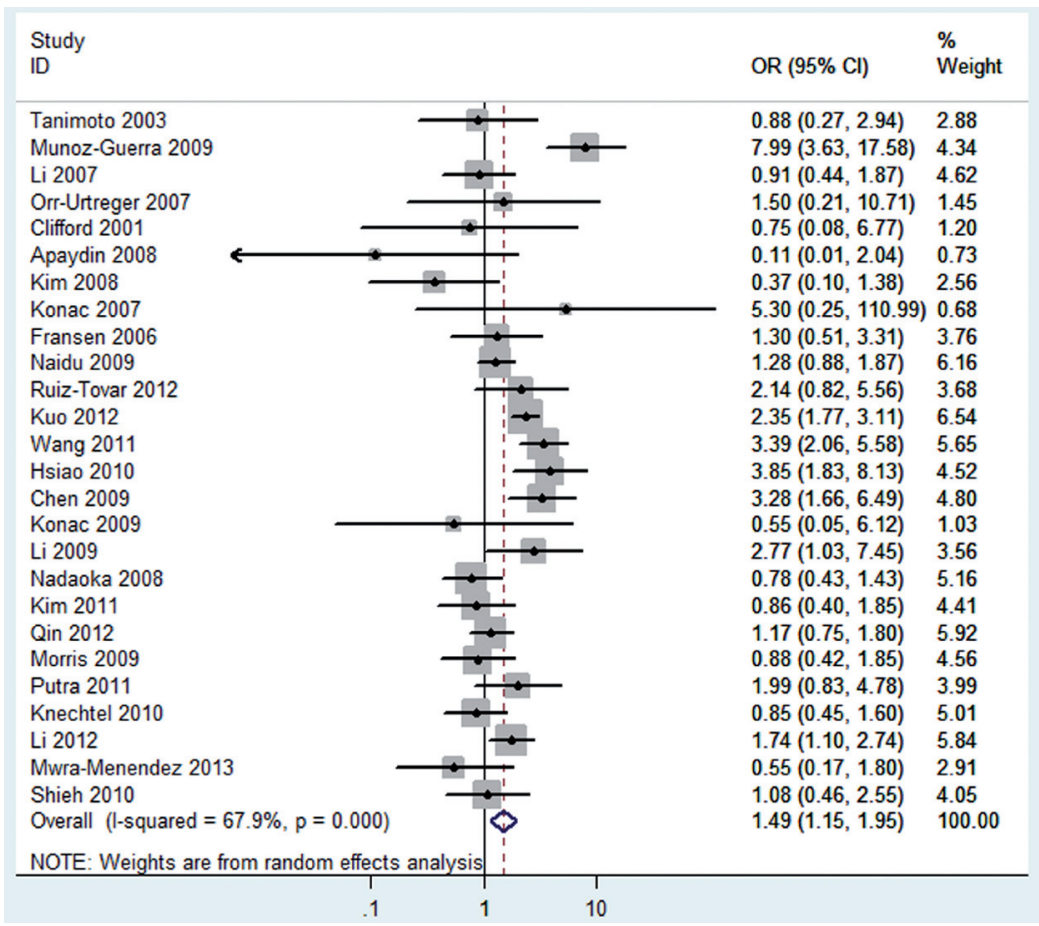

Figure 6. The forest plot of A vs. G of $1790 \mathrm{G} / \mathrm{A}$ polymorphism and overall cancer risk(random model).

The overall OR is shown. The OR of each study is marked with a grey square. The \%weight of OR is indicated by a shadow. The overall OR is indicated by blue diamond.

(rs11549467) polymorphism and a decreased gynecologic cancer risk. Furthermore, We found that Caucasian with AA genotype had higher risk of cancer compared to Asian under the homozygote and recessive models. Inconsistency between the two ethnicities can be explained by the possibility that different ethnic groups live with multiple life styles and environmental factors. And different populations carry different genotype and/or allele frequencies of this locus polymorphism which may lead to various degrees of cancer susceptibility. In our meta-analysis, we also observed inconsistent results between hospital-based studies and population-based studies. Our results show that controls in hospital-based studies are more representative of general population than controls from population-based studies. Several factors such as environmental factors and genetic backgrounds might contribute to the discrepancy.

There were some limitations in our meta-analysis. First, sample size in any given cancer was not sufficiently large, which could increase the probability of false positive or false negative results. It might be difficult to get a concrete conclusion if the number of included studies in subgroup was few. Besides, studies involved in different ethnicities were warranted to estimate the effects of this functional polymorphism on cancer risk. Second, due to the original data of the eligible studies was unavailable, it was difficult for us to evaluate the roles of some special environmental factors and lifestyles such as diet, alcohol consumption, and smoking status in developing cancer. Third, the influence of bias in the present analysis could not be completely excluded because positive results are supposed to be published much more quickly than articles with "negatives" results.

\section{Conclusions}

Our meta-analysis suggested that the Hif-1/HIF-1 1790G/ $\mathrm{A}(\mathrm{rs} 11549467)$ genetic polymorphism may contribute to the susceptibility of cancers except gynecologic cancer, especially in homozygote comparison (AA vs. GG) and recessive genetic model (AA vs. AG/GG) among Caucasian population, and this SNP was significantly associated with the lung cancer, pancreatic cancer and oral squamous cell carcinoma (OSCC). The phenomenon also indicates that the SNP functions as a recessive mutation, which needs to be verified or linked with functional studies. Large well designed epidemiological studies are needed to validate our findings.

\section{References}

[1] SIEGEL R, NAISHADHAM D, JEMAL A: Cancer statistics, 2012. CA Cancer J Clin 2012; 62: 10-29. http://dx.doi. org/10.3322/caac. 20138

[2] WRIGHT ME, PETERS U, GUNTER MJ, MOORE SC, LAWSON KA, et al.: Association of variants in two vitamin 
e transport genes with circulating vitamin e concentrations and prostate cancer risk. Cancer Res 2009; 69: 1429-1438. http://dx.doi.org/10.1158/0008-5472.CAN-08-2343

[3] CHEUNG WY, LIU G: Genetic variations in esophageal cancer risk and prognosis. Gastroenterol Clin North Am 2009; 38: 75-91. http://dx.doi.org/10.1016/j.gtc.2009.01.009

[4] RUAN K, SONG G, OUYANG G: Role of hypoxia in the hallmarks of human cancer. J Cell Biochem 2009; 107: 1053-1062. http://dx.doi.org/10.1002/jcb.22214

[5] BRAHIMI-HORN MC, POUYSSEGUR J: HIF at a glance. J Cell Sci 2009; 122: 1055-1057. http://dx.doi.org/10.1242/ jcs.035022

[6] BRAHIMI-HORN MC, CHICHE J, POUYSSEGUR J: Hypoxia and cancer. J Mol Med (Berl) 2007; 85: 1301-1307. http://dx.doi.org/10.1007/s00109-007-0281-3

[7] SCHMID T, ZHOU J, BRUNE B: HIF-1 and p53: Communication of transcription factors under hypoxia. J Cell Mol Med 2004; 8: 423-431. http://dx.doi.org/10.1111/j.1582-4934.2004. tb00467.x

[8] KOSHIJI M, TO KK, HAMMER S, KUMAMOTO K, HARRIS AL, et al.: HIF-1alpha induces genetic instability by transcriptionally downregulating MutSalpha expression. Mol Cell 2005; 17: 793-803. http://dx.doi.org/10.1016/j.molcel.2005.02.015

[9] CHAN N, KOCH CJ, BRISTOW RG: Tumor hypoxia as a modifier of DNA strand break and cross-link repair. Curr Mol Med 2009; 9: 401-410. http://dx.doi.org/10.2174/ 156652409788167050

[10] LEE YM, LIM JH, CHUN YS, MOON HE, LEE MK, et al.: Nutlin-3, an Hdm2 antagonist, inhibits tumor adaptation to hypoxia by stimulating the FIH-mediated inactivation of HIF1alpha. Carcinogenesis 2009; 30: 1768-1775. http://dx.doi. org/10.1093/carcin/bgp196

[11] HUANG LE, BINDRA RS, GLAZER PM, HARRIS AL: Hypoxia-induced genetic instability-a calculated mechanism underlying tumor progression. J Mol Med (Berl) 2007; 85: 139-148. http://dx.doi.org/10.1007/s00109-006-0133-6

[12] MENG AX, JALALI F, CUDDIHY A, CHAN N, BINDRA RS, et al.: Hypoxia down-regulates DNA double strand break repair gene expression in prostate cancer cells. Radiother Oncol 2005; 76: 168-176. http://dx.doi.org/10.1016/j.radonc.2005.06.025

[13] SEMENZA GL: Expression of hypoxia-inducible factor 1: Mechanisms and consequences. Biochem Pharmacol 2000; 59: 47-53. http://dx.doi.org/10.1016/S0006-2952(99)00292-0

[14] ZHONG H, DE MARZO AM, LAUGHNER E, LIM M, HILTON DA, et al.: Overexpression of hypoxia-inducible factor 1alpha in common human cancers and their metastases. Cancer Res 1999; 59: 5830-5835.

[15] TALKS KL, TURLEY H, GATTER KC, MAXWELL PH, PUGH CW, et al.: The expression and distribution of the hypoxia-inducible factors HIF-1alpha and HIF-2alpha in normal human tissues, cancers, and tumor-associated macrophages. Am J Pathol 2000; 157: 411-421. http://dx.doi.org/10.1016/ S0002-9440(10)64554-3

[16] BOS R, ZHONG H, HANRAHAN CF, MOMMERS EC, SEMENZA GL, et al.: Levels of hypoxia-inducible factor-1 alpha during breast carcinogenesis. J Natl Cancer Inst 2001; 93: 309-314. http://dx.doi.org/10.1093/jnci/93.4.309
[17] KOUKOURAKIS MI, PAPAZOGLOU D, GIATROMANOLAKI A, PANAGOPOULOS I, MALTEZOS E, et al.: C2028T polymorphism in exon 12 and dinucleotide repeat polymorphism in intron 13 of the HIF-1alpha gene define HIF-1alpha protein expression in non-small cell lung cancer. Lung Cancer-J Iaslc 2006; 53: 257-262. http://dx.doi. org/10.1016/j.lungcan.2006.05.025

[18] TZAO C, LEE SC, TUNG HJ, HSU HS, HSU WH, et al.: Expression of hypoxia-inducible factor (HIF)-1alpha and vascular endothelial growth factor (VEGF)-D as outcome predictors in resected esophageal squamous cell carcinoma. Dis Markers 2008; 25: 141-148. http://dx.doi.org/10.1155/ $2008 / 468323$

[19] KOUKOURAKIS MI, GIATROMANOLAKI A, SKARLATOS J, CORTI L, BLANDAMURA S, et al.: Hypoxia inducible factor (HIF-1a and HIF-2a) expression in early esophageal cancer and response to photodynamic therapy and radiotherapy. Cancer Res 2001; 61: 1830-1832.

[20] SEMENZA GL: Targeting HIF-1 for cancer therapy. Nat Rev Cancer 2003; 3: 721-732. http://dx.doi.org/10.1038/nrc1187 [21] CLIFFORD SC, ASTUTI D, HOOPER L, MAXWELL PH, RATCLIFFE PJ, et al.: The pVHL-associated SCF ubiquitin ligase complex: Molecular genetic analysis of elongin $\mathrm{B}$ and $\mathrm{C}$, Rbx1 and HIF-1alpha in renal cell carcinoma. Oncogene 2001; 20: 5067-5074. http://dx.doi.org/10.1038/sj.onc.1204602

[22] TANIMOTO K, YOSHIGA K, EGUCHI H, KANEYASU M, UKON K, et al.: Hypoxia-inducible factor-1alpha polymorphisms associated with enhanced transactivation capacity, implying clinical significance. Carcinogenesis 2003; 24: 17791783. http://dx.doi.org/10.1093/carcin/bgg132

[23] KUWAI T, KITADAI Y, TANAKA S, KURODA T, OCHIUMI T, et al.: Single nucleotide polymorphism in the hypoxiainducible factor-1alpha gene in colorectal carcinoma. Oncol Rep 2004; 12: 1033-1037.

[24] OLLERENSHAW M, PAGE T, HAMMONDS J, DEMAINE A: Polymorphisms in the hypoxia inducible factor-1alpha gene (HIF1A) are associated with the renal cell carcinoma phenotype. Cancer Genet Cytogenet 2004; 153: 122-126. http://dx.doi.org/10.1016/j.cancergencyto.2004.01.014

[25] CHAU CH, PERMENTER MG, STEINBERG SM, RETTER AS, DAHUT WL, et al.: Polymorphism in the hypoxia-inducible factor 1alpha gene may confer susceptibility to androgen-independent prostate cancer. Cancer Biol Ther 2005; 4: 1222-1225. http://dx.doi.org/10.4161/ cbt.4.11.2091

[26] FRANSEN K, FENECH M, FREDRIKSON M, DABROSIN C, SODERKVIST P: Association between ulcerative growth and hypoxia inducible factor-1alpha polymorphisms in colorectal cancer patients. Mol Carcinog 2006; 45: 833-840. http://dx.doi.org/10.1002/mc.20209

[27] KONAC E, ONEN HI, METINDIR J, ALP E, BIRI AA, et al.: An investigation of relationships between hypoxia-inducible factor-1 alpha gene polymorphisms and ovarian, cervical and endometrial cancers. Cancer Detect Prev 2007; 31: 102-109. http://dx.doi.org/10.1016/j.cdp.2007.01.001

[28] LI H, BUBLEY GJ, BALK SP, GAZIANO JM, POLLAK M, et al.: Hypoxia-inducible factor-1alpha (HIF-1alpha) gene 
polymorphisms, circulating insulin-like growth factor binding protein (IGFBP)-3 levels and prostate cancer. Prostate 2007; 67: 1354-1361. http://dx.doi.org/10.1002/pros.20589

[29] ORR-URTREGER A, BAR-SHIRA A, MATZKIN H, MABJEESH NJ: The homozygous P582S mutation in the oxygen-dependent degradation domain of HIF-1 alpha is associated with increased risk for prostate cancer. Prostate 2007; 67: 8-13. http://dx.doi.org/10.1002/pros.20433

[30] APAYDIN I, KONAC E, ONEN HI, AKBABA M, TEKIN E, et al.: Single nucleotide polymorphisms in the hypoxia-inducible factor-1alpha (HIF-1alpha) gene in human sporadic breast cancer. Arch Med Res 2008; 39: 338-345. http://dx.doi. org/10.1016/j.arcmed.2007.11.012

[31] HORREE N, GROOT AJ, VAN HATTEM WA, HEINTZ AP, VOOIJS M, et al.: HIF-1A gene mutations associated with higher microvessel density in endometrial carcinomas. Histopathology 2008; 52: 637-639.

[32] KIM HO, JO YH, LEE J, LEE SS, YOON KS: The C1772T genetic polymorphism in human HIF-1alpha gene associates with expression of HIF-1alpha protein in breast cancer. Oncol Rep 2008; 20: 1181-1187.

[33] LEE JY, CHOI JY, LEE KM, PARK SK, HAN SH, et al.: Rare variant of hypoxia-inducible factor-1alpha (HIF-1A) and breast cancer risk in Korean women. Clin Chim Acta 2008; 389: 167-170. http://dx.doi.org/10.1016/j.cca.2007.12.005

[34] FOLEY R, MARIGNOL L, THOMAS AZ, CULLEN IM, PERRY AS, et al.: The HIF-1alpha C1772T polymorphism may be associated with susceptibility to clinically localised prostate cancer but not with elevated expression of hypoxic biomarkers. Cancer Biol Ther 2009; 8: 118-124. http://dx.doi. org/10.4161/cbt.8.2.7086

[35] MARIGNOL L, FOLEY R, SOUTHGATE TD, COFFEY M, HOLLYWOOD D, et al.: Hypoxia response element-driven cytosine deaminase/5-fluorocytosine gene therapy system: A highly effective approach to overcome the dynamics of tumour hypoxia and enhance the radiosensitivity of prostate cancer cells in vitro. J Gene Med 2009; 11: 169-179. http://dx.doi. org/10.1002/jgm.1281

[36] MUNOZ-GUERRA MF, FERNANDEZ-CONTRERAS ME, MORENO AL, MARTIN ID, HERRAEZ B, et al.: Polymorphisms in the hypoxia inducible factor 1-alpha and the impact on the prognosis of early stages of oral cancer. Ann Surg Oncol 2009; 16: 2351-2358. http://dx.doi.org/10.1245/s10434-0090503-8

[37] SMALDONE MC, MARANCHIE JK: Clinical implications of hypoxia inducible factor in renal cell carcinoma. Urol Oncol 2009; 27: 238-245. http://dx.doi.org/10.1016/ j.urolonc.2007.12.001

[38] LING TS, SHI RH, ZHANG GX, ZHU H, YU LZ, et al.: Common single nucleotide polymorphism of hypoxia-inducible factor-1alpha and its impact on the clinicopathological features of esophageal squamous cell carcinoma. Chin J Dig Dis 2005; 6: 155-158. http://dx.doi.org/10.1111/j.14439573.2005.00223.x

[39] DERSIMONIAN R, LAIRD N: Meta-analysis in clinical trials. Control Clin Trials 1986; 7: 177-188. http://dx.doi. org/10.1016/0197-2456(86)90046-2
[40] MANTEL N, HAENSZEL W: Statistical aspects of the analysis of data from retrospective studies of disease. J Natl Cancer Inst 1959; 22: 719-748.

[41] HIGGINS JP, THOMPSON SG, DEEKS JJ, ALTMAN DG: Measuring inconsistency in meta-analyses. BMJ 2003; 327: 557-560. http://dx.doi.org/10.1136/bmj.327.7414.557

[42] EGGER M, DAVEY SG, SCHNEIDER M, MINDER C: Bias in meta-analysis detected by a simple, graphical test. BMJ 1997; 315: 629-634. http://dx.doi.org/10.1136/bmj.315.7109.629

[43] TANIMOTO K, YOSHIGA K, EGUCHI H, KANEYASU M, UKON K, et al.: Hypoxia-inducible factor-1alpha polymorphisms associated with enhanced transactivation capacity, implying clinical significance. Carcinogenesis 2003; 24: 17791783. http://dx.doi.org/10.1093/carcin/bgg132

[44] LI H, BUBLEY GJ, BALK SP, GAZIANO JM, POLLAK M, et al.: Hypoxia-inducible factor-1alpha (HIF-1alpha) gene polymorphisms, circulating insulin-like growth factor binding protein (IGFBP)-3 levels and prostate cancer. Prostate 2007; 67: 1354-1361. http://dx.doi.org/10.1002/pros.20589

[45] NADAOKA J, HORIKAWA Y, SAITO M, KUMAZAWA T, INOUE T, et al.: Prognostic significance of HIF-1 alpha polymorphisms in transitional cell carcinoma of the bladder. Int J Cancer 2008; 122: 1297-1302. http://dx.doi.org/10.1002/ ijc. 23256

[46] CHEN MK, CHIOU HL, SU SC, CHUNG TT, TSENG HC, et al.: The association between hypoxia inducible factorlalpha gene polymorphisms and increased susceptibility to oral cancer. Oral Oncol 2009; 45: e222-e226. http://dx.doi. org/10.1016/j.oraloncology.2009.07.015

[47] KONAC E, DOGAN I, ONEN HI, YURDAKUL AS, OZTURK C, et al.: Genetic variations in the hypoxia-inducible factor-1alpha gene and lung cancer. Exp Biol Med (Maywood) 2009; 234: 1109-1116. http://dx.doi.org/10.3181/0902-RM49

[48] LI K, ZHANG Y, DAN Z, WANG Y, REN ZC: Association of the hypoxia inducible factor-1alpha gene polymorphisms with gastric cancer in Tibetans. Biochem Genet 2009; 47: 625-634. http://dx.doi.org/10.1007/s10528-009-9254-2

[49] MORRIS MR, HUGHES DJ, TIAN YM, RICKETTS CJ, LAU $\mathrm{KW}$, et al.: Mutation analysis of hypoxia-inducible factors HIF1A and HIF2A in renal cell carcinoma. Anticancer Res 2009; 29: 4337-4343.

[50] NAIDU R, HAR YC, TAIB NA: Associations between hypoxiainducible factor-1alpha (HIF-1alpha) gene polymorphisms and risk of developing breast cancer. Neoplasma 2009; 56: 441-447. http://dx.doi.org/10.4149/neo $200905 \quad 441$

[51] MUNOZ-GUERRA MF, FERNANDEZ-CONTRERAS ME, MORENO AL, MARTIN ID, HERRAEZ B, et al.: Polymorphisms in the hypoxia inducible factor 1-alpha and the impact on the prognosis of early stages of oral cancer. Ann Surg Oncol 2009; 16: 2351-2358. http://dx.doi.org/10.1245/s10434-0090503-8

[52] HSIAO PC, CHEN MK, SU SC, UENG KC, CHEN YC, et al.: Hypoxia inducible factor-1alpha gene polymorphism G1790A and its interaction with tobacco and alcohol consumptions increase susceptibility to hepatocellular carcinoma. J Surg Oncol 2010; 102: 163-169. http://dx.doi.org/10.1002/jso.21539 
[53] KIM YH, PARK IA, PARK WY, KIM JW, KIM SC, et al.: Hypoxia-inducible factor 1alpha polymorphisms and earlystage cervical cancer. Int J Gynecol Cancer 2011; 21: 2-7. http://dx.doi.org/10.1097/IGC.0b013e318204f6e6

[54] PUTRA AC, TANIMOTO K, ARIFIN M, HIYAMA K: Hypoxia-inducible factor-1alpha polymorphisms are associated with genetic aberrations in lung cancer. Respirology 2011; 16: 796-802. http://dx.doi.org/10.1111/j.1440-1843.2011.01972. x

[55] WANG X, LIU Y, REN H, YUAN Z, LI S, et al.: Polymorphisms in the hypoxia-inducible factor-1alpha gene confer susceptibility to pancreatic cancer. Cancer Biol Ther 2011; 12: 383-387. http://dx.doi.org/10.4161/cbt.12.5.15982

[56] KUO WH, SHIH CM, LIN CW, CHENG WE, CHEN SC, et al.: Association of hypoxia inducible factor-1alpha polymorphisms with susceptibility to non-small-cell lung cancer. Transl Res 2012; 159: 42-50. http://dx.doi.org/10.1016/ j.trsl.2011.09.003

[57] QIN C, CAO Q, JU X, WANG M, MENG X, et al.: The polymorphisms in the VHL and HIF1A genes are associated with the prognosis but not the development of renal cell carcinoma. Ann Oncol 2012; 23: 981-989. http://dx.doi.org/10.1093/annonc/mdr325

[58] RUIZ-TOVAR J, FERNANDEZ-CONTRERAS ME, MARTIN-PEREZ E, GAMALLO C: Association of thymidylate synthase and hypoxia inducible factor-1alpha DNA polymorphisms with pancreatic cancer. Tumori 2012; 98: 364-369.

[59] SHIEH TM, CHANG KW, TU HF, SHIH YH, KO SY, et al.: Association between the polymorphisms in exon 12 of hypoxia-inducible factor-1alpha and the clinicopathological features of oral squamous cell carcinoma. Oral Oncol 2010; 46: e47-e53. http://dx.doi.org/10.1016/j.oraloncology.2010.0 $\underline{4.009}$

[60] LI P, CAO Q, SHAO PF, CAI HZ, ZHOU H, et al.: Genetic polymorphisms in HIF1A are associated with prostate cancer risk in a Chinese population. Asian J Androl 2012; 14: 864-869. http://dx.doi.org/10.1038/aja.2012.101

[61] MERA-MENENDEZ F, HINOJAR-GUTIERREZ A, GUIJARRO RM, DE GREGORIO JG, MERA-MENENDEZ E, et al.: Polymorphisms in HIF-1alpha affect presence of lymph node metastasis and can influence tumor size in squamouscell carcinoma of the glottic larynx. Clin Transl Oncol 2013; 15: 358-363. http://dx.doi.org/10.1007/s12094-012-0930-Z

[62] KNECHTEL G, SZKANDERA J, STOTZ M, HOFMANN G, LANGSENLEHNER U, et al.: Single nucleotide polymorphisms in the hypoxia-inducible factor-1 gene and colorectal cancer risk. Mol Carcinog 2010; 49: 805-809.

[63] SMALDONE MC, MARANCHIE JK: Clinical implications of hypoxia inducible factor in renal cell carcinoma. Urol Oncol 2009; 27: 238-245. http://dx.doi.org/10.1016/ j.urolonc.2007.12.001

[64] TANIMOTO K, YOSHIGA K, EGUCHI H, KANEYASU M, UKON K, et al.: Hypoxia-inducible factor-1alpha polymorphisms associated with enhanced transactivation capacity, implying clinical significance. Carcinogenesis 2003; 24: 1779-1783. http://dx.doi.org/10.1093/carcin/bgg132

[65] ZHAO T, LV J, ZHAO J, NZEKEBALOUDOU M: Hypoxiainducible factor-1alpha gene polymorphisms and cancer risk: A meta-analysis. J Exp Clin Cancer Res 2009; 28: 159. http://dx.doi.org/10.1186/1756-9966-28-159 